\title{
$\mathrm{Ni}-\mathrm{Zn}$ 系フェライトの初透磁率の温度変化について*
}

\author{
窪田武一林西川友 三***
}

\section{On the Temperature Dependency of Initial Permeability for Ni-Zn Ferrites}

\author{
by \\ Buichi Kubota and Tomozo NishikawA \\ (Matsushita Elect. Co. Ltd.)
}

The temperature dependency of initial permeability for $\mathrm{Ni}-\mathrm{Zn}$ ferrites is required to be made as small as possible, when the ferrites are used in electronic components. The present paper describes a method to improve the temperature dependency of the initial permeability for $\mathrm{Ni}-\mathrm{Zn}$ ferrites.

Initial permeability $\mu_{0}$ is represented in terms of saturation magnetization; $I_{S}$, magnetostriction $; \lambda_{S}$, internal stress $; \sigma$, and magnetic anisotropy ; $K$,

$$
\mu_{0} \propto \frac{I_{S}{ }^{2}}{\lambda_{S} \sigma+|K|}
$$

Since $I_{S}, \lambda_{S}, \sigma$ and $K$ have temperature dependency, initial permeability varies with temperature.

Authors, therefore, studied the relation between temperature dependency of $\mu_{0}$ and heat-treatment of ferrite which was given to obtain different $K$ or $\lambda_{S} \sigma$.

The composition of studied ferrites are $(\mathrm{NiO})_{0 \cdot 3}(\mathrm{ZnO})_{0 \cdot 2}\left(\mathrm{Fe}_{2} \mathrm{O}_{3}\right)_{0 \cdot 5}$ and $(\mathrm{NiO})_{0 \cdot 35}(\mathrm{ZnO})_{0 \cdot 15}\left(\mathrm{Fe}_{2} \mathrm{O}_{3}\right)_{0 \cdot 5}$. These oxides were fired at a temperature between $1150^{\circ} \mathrm{C}$ and $1275^{\circ} \mathrm{C}$ after calcining at various temperatures.

Experimental results obtained were as follows :

(1) Small temperature factor of $\mu_{0}$ was not obtained only by changing conditions of heat-treatment.

(2) Specimens of $\mathrm{Ni}-\mathrm{Zn}$ ferrite in which Co-ferrites was dissolved show various $\mu_{0}-T$ relations as the heat-treatment or Co-ferrite content varies.

(3) To minimize temperature dependency of $\mu_{0}$ at a temperature range of $-30^{\circ} \mathrm{C} \sim+50^{\circ} \mathrm{C}$, $1 \sim 1.25 \mathrm{~mol} \%$ of Co-ferrite must be dissolved in $\mathrm{Ni}-\mathrm{Zn}$ ferrite.

(4) As the temperature dependency of $\mu_{0}$ for $\mathrm{Ni}-\mathrm{Zn}$ ferrites in which Co-ferrites was dissolved is varied by varying the calcining and firing temperature, the condition of heat-treatment

for these ferrites must always be considered carefully.

(Received Jan. 9, 1961)

\section{1. 緒言}

$\mathrm{Ni}-\mathrm{Zn}$ 系のフェライトは通信機器部品として，放送 受信用アンテナ, 中間周波変性器などの磁心に用いら れるが,一般に通信機器に用いられるフェライト磁心 はその特性の温度変化ができるだけ小さいことが望ま れている。たとえば最近よく用いられている携帯式の 小形ラジオの中には，これを寒冷地などで室内外に持 ち歩くとき, 温度の急变のためにアンテナ磁心の透磁 率が変化して, 同調のずれるようなこともある. その

* 原稿受付 昭和 36 年 1 月 9 日, 窒業協会大阪支部学術講演会に ** 松下電器産業株式会社無線事業本部研究部

**** 正員 松下電器産業株式会社無線事業本部研究部
ためにラジオアンテナ磁心に用いられる $\mathrm{Ni}-\mathrm{Zn}$ 系の フェライト磁心もその透磁率の温度変化ができるだけ 小さいことが望まれるようになった。

一般に, Ni- $\mathrm{n}$ 系フェライトの初透磁率は, Fig. 1) に示すように, 温度とともに上昇し, その温度変化の 程度は $\mathrm{NiO}$ と $\mathrm{ZnO}$ の比によって定まるものである. その理由は, 初透磁率が式(1)の関係によって表わさ れ, 右辺の $I_{S}, \lambda_{S} \sigma, K$ のいずれもが温度とともに变 化するために起こるものである.

$$
\begin{aligned}
& \mu_{0} \propto \frac{I_{S}{ }^{2}}{\lambda_{S} \sigma+|K|} \\
& \mu_{0} ; \quad \text { 初透磁率 }
\end{aligned}
$$


$I_{S} ;$ 飽和磁化

$\lambda_{S}$; 磁わい定数

$\sigma$; 内部応力

$K$ ： 結晶磁気異方性

式(1)における $I_{S}, \lambda_{S} \sigma,|K|$ などの值はいずれも温 度の上升とともにその值が減少するが，その变化の状 態はすべて異なっており，一般には $I_{S}$ の減少よりも， $|K|$ その他の減少のほうが大きいために, $\mu_{0}$ は温度と ともに上年することになる。また $\mathrm{ZnO}: \mathrm{NiO}$ の比が 大きくなるほど $|K|$ の值は小さく，そのために $\mu_{0}$ の 值が大きくなるとともにキューリ一温度も下がり $\mu_{0}$ の 温度変化は大きくなる。

一方， $I_{S}, \lambda_{s} \sigma, K$ などの值は, フェライトの組成が 定まればたいてい決ってしまうものであるが，そのほ かに微量の添加物, 原料酸化物間の反応ならびに焼結 の程度, 熱处理後の冷却条件などによってある程度変 化させることができ，それによって $\mu_{0}$ の温度変化をあ る程度人為的に変化させることが可能である.

この報告は Fig. 1 に示されるように $\mu_{0}$ が温度変化 をする $\mathrm{Ni}-\mathrm{Zn}$ フェライトを対象として，上述の条件 を考慮することにより， $\mu_{0}$ の温度変化をほとんど持た ない Ni-Zn フェライトを造り出すよう検討したもの である.

\section{2. 供 試 材 料}

フェライトの作成方法は普通一般に行なわれる耐火 れんがや陶磁器などの墨業製品の場合となんら異なら ない，すなわち原料である金属酸化物をボールミル中 で水とともに混合, 粉䂗し, 乾燥後適当な形に成形し, $600 \sim 1100^{\circ} \mathrm{C}$ の温度で仮焼, 再び粉研, 成形しての ち，1150 1 $1275^{\circ} \mathrm{C}$ の間で本焼成する，それぞれの試 料の仮焼温度, 本焼成温度およびそれらの温度での保 持時間は “実験法と実験結果”のところで詳記する。 また䓩成はすべて空気中で行なった。用いた原料の純 度は $\mathrm{Fe}_{2} \mathrm{O}_{3} ; 99 \cdot 2 \%, \mathrm{NiO} ; 98 \cdot 7 \%, \mathrm{ZnO} ; 99 \cdot 9 \%$ 程

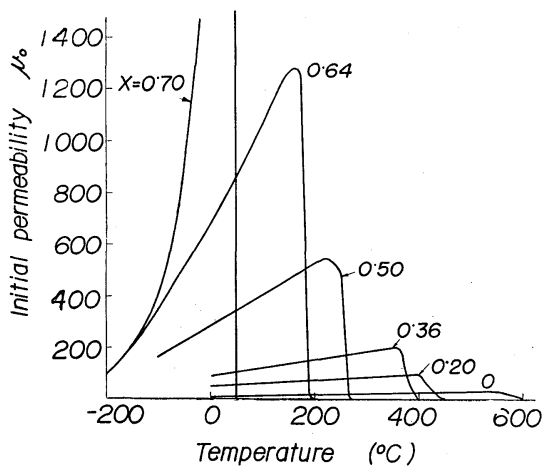

Fig. 1 Initial permeability as a function of temperature for mixed nickel-zinc ferrites, $\mathrm{Ni}_{1-x} \mathrm{Zn}_{x} \mathrm{Fe}_{2} \mathrm{O}_{4}$
度のものである、Ni-Znフェライトの配合組成として は $\mathrm{NiO} ; 30 \mathrm{~mol} \%, \mathrm{ZnO} ; 20 \mathrm{~mol} \%, \mathrm{Fe}_{2} \mathrm{O}_{3} ; 50 \mathrm{~mol}$ \%および $\mathrm{NiO} ; 35 \mathrm{~mol} \%, \mathrm{ZnO} ; 15 \mathrm{~mol} \%, \mathrm{Fe}_{2} \mathrm{O}_{3}$; $50 \mathrm{~mol} \%$ \% 種類を選んだ。その理由は，この範囲の 配合組成から得られる $\mathrm{Ni}-\mathrm{Zn}$ フェライトは, その初 透磁率の分散が $20 \mathrm{Mc}$ 前後の周波数で起こり, 中短 波用ラジオ受信機のアンテナ磁心として最もよく使用 されるからである。

試験に供した試料は，初透磁率の測定に便ならしめ るため, 外径; $36 \mathrm{~mm}$, 内径 ; $24 \mathrm{~mm}$, 高さ ; $8 \mathrm{~mm}$ のリングになるように金型を用いて 1 ton $/ \mathrm{cm}^{2}$ の成 形圧力で成形した.

\section{3. 実 験 装 置}

初透硫率 $\mu_{0}$ の測定には横河電機製 $\mathrm{Q}$ メーター $(\mathrm{QM}$ -102A)を用い，試料にはりッッ線 $(0.06 \mathrm{~mm} \phi$ の 10 本より）を必要な巻数だけ巻き，所定の周波数で同調 容量を測定し, 式( 2 )にしたがって計算した.

$$
\mu_{0}=6 \cdot 35 \times \frac{d}{S(N f)^{2}\left(C+C_{0}\right)} \times 10^{6}
$$

ただし， $f$; 測定周波数 $(\mathrm{Mc}), C$; 同調容量 $(p F)$, $d$; 試料の平均直径 $(\mathrm{cm}), S$; 試料の断面積 $\left(\mathrm{cm}^{2}\right)$, $N$; 巻線の巻数, $C_{0}$; 巻線の分布容量 $(p F)$ で次式か ら計算する。

$$
C_{0}=\frac{C_{1}-n^{2} C_{2}}{n^{2}-1}
$$

すなわち, 巻線の分布容量 $C_{0}$ は二つの周波数 $f_{1}$ お よび $n f_{1}$ で同調容量 $C_{1}$ および $C_{2}$ を測定する。 $n$ は 二つの周波数の比である.

一方， $\mu_{0}$ の温度変化を測定するためには試料を連続 的に加熱，冷却する装置が必要である。その目的のた めに Fig. 2 に示すような構造の恒温槽を用いた。こ の恒温慒内には絶えず空気が循環していて, 温度を上 畀するときには上部にあるニクロム線で空気を加熱し， また冷却するとさには固体炭酸または炭酸ガスボンベ から直接炭酸ガスを吹き出させ，空気を冷却しつつ同 時に冷い炭酸ガスをそのまま循環させる，冷却をすみ やかに行ないたいときには炭酸ガスボンベを用いたほ うが効果的である。温度制御は高精度の電子管式制御

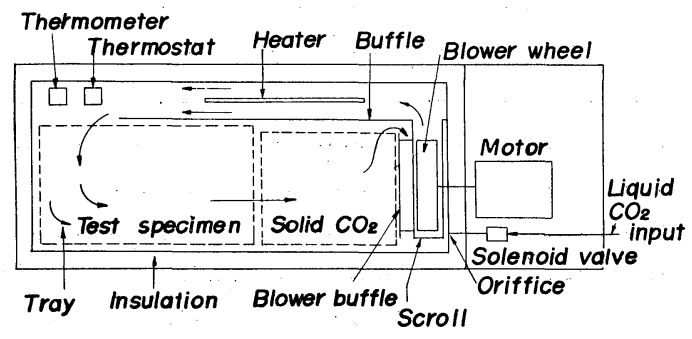

Fig. 2 Temperature factor test chamber (Statham, type TC-15B, U.S.A.) 
計器で行なわれ, 加熱時は電熱器で, 冷却時は固体炭 酸を用いるときは電熱器と併用で, 炭酸ガスボンベを 用いるどきはバルブの開閉で温度が一定に保持される。 この恒温槽の温度調節範囲は $-70^{\circ} \mathrm{C} \sim+400^{\circ} \mathrm{C}$, 制御 精度は $\pm 0.5^{\circ} \mathrm{C}$, 最大年温速度 $20^{\circ} \mathrm{C} / \mathrm{min}$, 最大降温

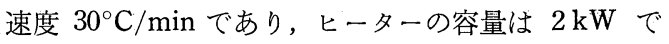
ある。

$\mu_{0}$ の温度変化を測定しようとする試料は巻線を施し て恒温槽内に入れ，巻線の両端を槽外に取り出してQ メーターにつなぎ, $\mu_{0}$ を測定しながら恒温槽の温度を 変化させる。

なお，ここでは $\mu_{0}$ の温度変化を表わす方法として 次式を用い，この值を $\mu_{0}$ の温度係数 (Temperature factor of initial permeability) と呼ぶことにした.

$$
\mu_{0} \text { の温度係数 }=\frac{\Delta \mu_{0}}{\left(\mu_{0} a v .\right)^{2} \Delta T}
$$

ただし $\Delta T$; 温度差, $T_{2}-T_{1}$

$\Delta \mu_{0} ；$ 温度 $T_{1}, T_{2}$ における $\mu_{0}$ の值の差

$\mu_{0 a v}$ ； 温度 $T_{1}, T_{2}$ 間の平均の $\mu_{0}$

このような値を用いるのは同じ材質で実效透磁率㸡 なる磁心を造ったとき，これを用いたインダクタンス 部品のインダクタンスの温度変化 $(\Delta L / L \cdot \Delta T)$ はこの $\mu_{0}$ の温度係数の值に $\left(\mu_{e}-1\right)$ を乗じたものに比例し, それゆえ,インダクタンスの温度变化によって生ずる 同調周波数のずれもこの関係によって容易に近似され るからである。

\section{4. 実験法と実験結果}

\section{（I）焼成条件の差による $\mu_{0}$ の温度变化}

緒言で述べたように， $\mu_{0}$ の温度変化はその材料のも つ飽和磁化, 磁わい定数, 内部応力および結晶磁気異 方性の温度变化によって定まる。それゆえ，ある材料 の $\mu_{0}$ の温度変化を解析していくためには，これらの 項目をそれぞれ別個に考えていくのが妥当と考えられ る。これらの項目のうち， $I_{S}$ および $K$ は材料の組成 が定まれば決ってしまうので，試料の作成条件から比 較的容易に变化せしめうるものは $\lambda_{S} \sigma$ の項であると考 えられる。すすわち焼成温度, 烧成後の冷却の条件を 変えれば，フェライト焼結体の内部に発生する内部応 力の状態が変わると考えられる。したがって磁わいの 状態も異なった材料が得られると考えられる。

試料の焼成条件を変化させると初透磁率の温度依存 性が異なってくるという例を $\mathrm{Mn}-\mathrm{Zn}$ フェライトの場 合について Fig. 3 に示すが, 同一材料であっても， その透磁率の温度変化は必ずしも一定であるとは言え ない，それゆえ，種々の温度で試料を焼成するととも に, 焼成後 Fig. 4 に示すように種々の冷却曲線にし たがって試料を冷却し，得られたフェライトの $\mu_{0}$ の 温度変化を調べた：Fig. 4 で C-1 と名づけたのは試
料を最高温度に所定時間保持後, 試料を炬から取り出 して空気中で冷却した場合，C-2 は炉内放冷，C-3 は $100^{\circ} \mathrm{C} / \mathrm{hr}, \mathrm{C}-4$ は $50^{\circ} \mathrm{C} / \mathrm{hr}$ で冷却した場合である。

Fig. 5 は配合組成 $\mathrm{NiO} ; 30 \mathrm{~mol} \%, \mathrm{ZnO} ; 20 \mathrm{~mol}$ $\%, \mathrm{Fe}_{2} \mathrm{O}_{3} ; 50$ mol\%のものを 1 150, 1175，1200 お よび $1230^{\circ} \mathrm{C}$ でそれぞれ 2 時間焼成し， $100^{\circ} \mathrm{C}, 1 \mathrm{hr}$ の速度で冷却することによって得られたフェライトの

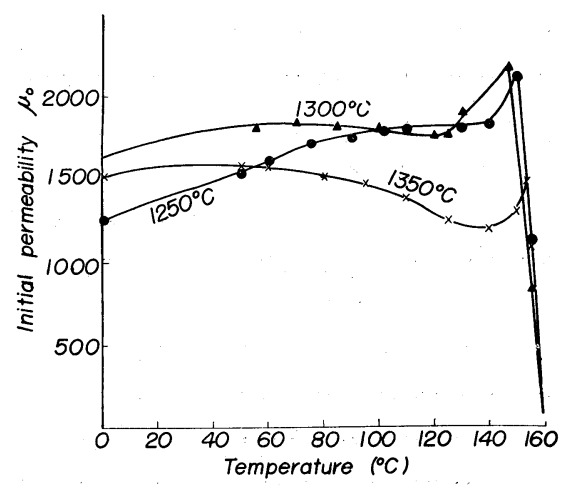

Fig. 3 Temperature dependency of initial permeability for $\mathrm{Mn}_{0.5} \mathrm{Zn}_{0.5} \mathrm{Fe}_{2} \mathrm{O}_{4}$ fired at various temperatures

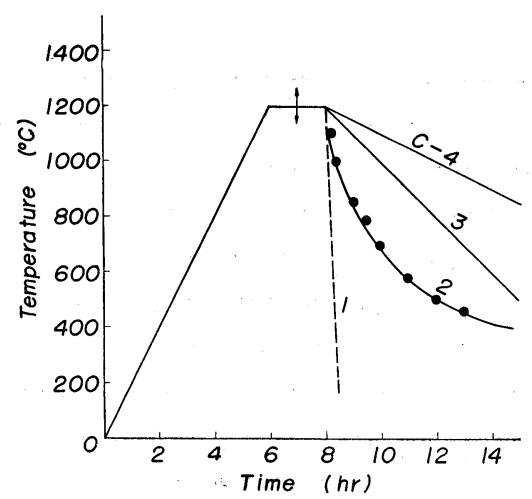

Fig. 4 Heating and cooling schedule for preparation of specimens

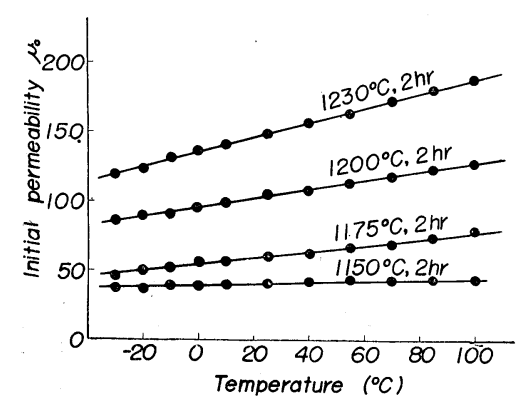

Fig. 5 Temperature dependency of initial permeability for $\mathrm{Ni}_{0.6} \mathrm{Zn}_{0.4} \mathrm{Fe}_{2} \mathrm{O}_{4}$ fired at various temperatures 
$\mu_{0}$-温度の関係を表わす図である。一般の $\mathrm{Ni}-\mathrm{Zn} フ ェ$ ライトにみられるように $\mu_{0}$-温度の関係はほとんど直 線であって, 焼成温度が高くなるほど $\mu_{0}$ の温度勾配 は大きくなり，焼成温度の低い場合には $\mu_{0}$ の変化は 小さいが, $\mu_{0}$ の絶対值が小さいために, Table 1 に見 られるように実用特性としての温度係数 $\Delta \mu_{0} /\left(\mu_{0} a v .\right)^{2}$. $\Delta T$ の值はむしろ高温度で焼成したもののほうが小さ いくらいである. Table 1 には $\mathrm{NiO}$; 30 mol\%, $\mathrm{ZnO} ; 20 \mathrm{~mol} \%, \mathrm{Fe}_{2} \mathrm{O}_{3} ; 50 \mathrm{~mol} \%$ 配合組成のもの につき, 種々の熱処理によって得られた $\mathrm{Ni}-\mathrm{Zn} フ ェ$ ライトの温度係数の值を示すが, 熱処理の条件を变え ただけでは, $\mu_{0}$ の温度係数はほとんど変わらないよう に考えられる. なおもっと回数を多く実験を行なって 解析すればそれぞれの処理条件によって差を見出すこ とができるかもしれないが, 温度係数を飛躍的に減少 せしめることを目的とするかぎり，焼成条件を变化す るのみでは充分な効果は収めえないと考えられる。

なおここでは暁成条件を変えて内部応力 $\sigma$ の状態の 異なった試料を作成して実験を試みたが， $\sigma$ は $\mu_{0}$ の温 度变化に及ぼす影響よりも，むしろ時間とともに緩和 して， $\mu_{0}$ の経時変化に与える影響のほうが大きいので はないかと考えられる。

\section{（II） 微量のコバルトフェライトを固溶した場合の} $\mu_{0}$ の温度变化

前節では, $\mathrm{Ni}-\mathrm{Zn}$ フェライトを単に焼成条件を变え て造っただけでは， $\mu_{0}$ の温度係数は飛躍的に小さくな らないということを述べたが，ここでは異方性定数 $K$ の温度变化を利用することについて述べたい，その場 合に $\mu_{0}$ の温度係数が熱処理の条件によってどのよう に変わるかということについて考察したい。

よく知られているように, $\mathrm{Ni}-\mathrm{Zn}$ フェライトトの結晶

Table 1 Temperature factor of initial permeability for $\mathrm{Ni}_{0 \cdot 6} \mathrm{Zn}_{0} \cdot{ }_{4} \mathrm{Fe}_{2} \mathrm{O}_{4}$ which was obtained by different heat-treatment

\begin{tabular}{|c|c|c|c|c|c|}
\hline \multicolumn{2}{|c|}{ Heat-treatment } & \multirow{2}{*}{\multicolumn{4}{|c|}{$\begin{array}{c}\text { Temperature factor, } \\
\Delta \mu_{0} /\left(\mu_{0} a v\right)^{2} \Delta T \times 10^{6}\end{array}$}} \\
\hline \multirow{2}{*}{$\begin{array}{r}\text { Calcining } \\
\text { temp., keep } \\
\text { time } \\
\left({ }^{\circ} \mathrm{C}\right)(\mathrm{hr})\end{array}$} & \multirow{2}{*}{$\mid \begin{array}{c}\text { Firing } \\
\text { temp., keep. } \\
\text { time } \\
\left({ }^{\circ} \mathrm{C}\right)(\mathrm{hr})\end{array}$} & & & & \\
\hline & & $\mathrm{C}-1$ & $\mathrm{C}-2$ & $\mathrm{C}-3$ & $C-4$ \\
\hline & $1150, \quad 2$ & $30 \cdot 5$ & $24 \cdot 1$ & $22 \cdot 6$ & $26 \cdot 3$ \\
\hline & $1175, \quad 2$ & $24 \cdot 7$ & $22 \cdot 0$ & $51 \cdot 3$ & $22 \cdot 8$ \\
\hline & $1200, \quad 2$ & $25 \cdot 1$ & $20 \cdot 6$ & $19 \cdot 1$ & $20 \cdot 5$ \\
\hline 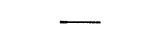 & $1230, \quad 2$ & $27 \cdot 2$ & $21 \cdot 2$ & $20 \cdot 4$ & $21 \cdot 0$ \\
\hline $1100, \quad 1$ & $1150, \quad 2$ & $19 \cdot 0$ & $18 \cdot 3$ & $19 \cdot 7$ & $14 \cdot 3$ \\
\hline $1100, \quad 1$ & $1175, \quad 2$ & $15 \cdot 3$ & $21 \cdot 0$ & $16 \cdot 4$ & $15 \cdot 7$ \\
\hline $1100, \quad 1$ & $1200, \quad 2$ & $10 \cdot 8$ & $16 \cdot 5$ & $13 \cdot 8$ & $21 \cdot 4$ \\
\hline $1100, \quad 1$ & $1230, \quad 2$ & $17^{\circ} 1$ & $13 \cdot 1$ & $9 \cdot 5$ & $12 \cdot 0$ \\
\hline
\end{tabular}

磁気異方性定数 $K$.は, Fig. 6 の曲線 $a$ のような温度 特性をもち, またその $\mu_{0}$ の温度変化は曲線 $d$ のちお りである、いまこれに曲線 $b$ で表わされるような異方 性定数 $K$ をもつ物質を適当量固溶させるとすると, $K$ が曲線 $c$ のような温度变化する物質が得られるが，か かる物質の $\mu_{0}$ は, 曲線 $c$ が温度軸を切る点で, すなわ ち $K=0$ とおいた場合の式( 1 )からもわかるように極 大を示すはずであるから， $a$ の物質に $b$ の物質を固溶 させることによってその物質の $\mu_{0}$-温度曲線は Fig. 6 の曲線 $d$ から $e$ のように変化させうる. すなわち, $\mu_{0}$ 一温度特性曲線において， $\mu_{0}$ が極大值をもつような材 料が得られ, それによって $\mu_{0}$ の極大点よりやや高い温 度域, すなわち $\mu_{0}$ が極小值を示す近辺の温度において $\mu_{0}$ の温度变化の小さいような材料の得られることがわ かる. 一方, $\mu_{0}$ が極大值を示す温度は $b$ の物質の固溶 量を加減することによって変化させることができるの で, $\mu_{0}$-温度特性曲線の谷の位置, すなわち $\mu_{0}$ の温度 変化の小さい温度範团を希望する範囲にもってくるこ とができる.

このように $\mu_{0}$ が極大值をもつような材料において は, この $\mu_{0}$ の極大の值は $a$ の物質と $b$ の物質の固溶 の完成度によって変化すると予測される。一方, アン テナ磁心などとして実際にフェライトを造る場合には， 種々の特性の上の要求から固体反応や焼結反応が充分 に進行した状態ではないので, これらの反応の程度に よって Fig. 6 の曲線 $e$ の極大值の大きさを適当に加 减し, 極大, 極小值の近辺の温度で極端に $\mu_{0}$ が温度 をしないようなものを造ることが可能であると考えら

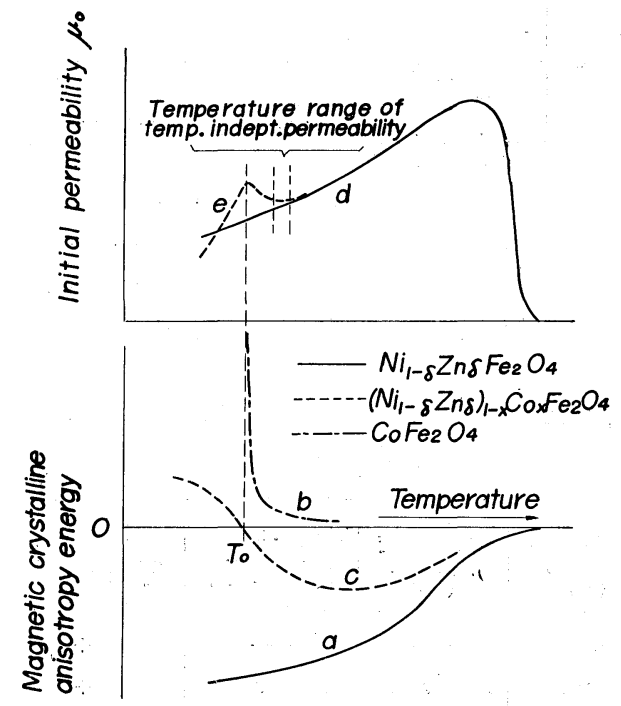

Fig. 6 Anomalies of initial permeability about the temperature to where the crystal anisotropy pass through zero, owing to the presence of a small amount of cobalt in

$\left(\mathrm{Ni}_{1-\delta} \dot{Z} \mathrm{Z}_{\delta}\right)_{1-x} \mathrm{Co}_{x} \mathrm{Fe}_{2} \mathrm{O}_{4}$ 


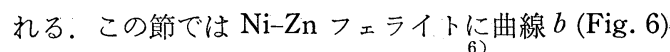
に相当する物質としてCo-フェライトを用い，これを 種々の熱処理条件の下で固溶させて得られたフェライ トの $\mu_{0}$-温度関係を測定し, 熱処理条件と $\mu_{0}$ の温度係 数との関係について考察することにした.

試験に供したフェライトの作成法は前述のとおり であるが， $\mathrm{Co}$ ーフライトの原料としては $2 \mathrm{CoCO}_{3}$. $3 \mathrm{Co}(\mathrm{OH})_{2}$ を用い, 配合組成としては熱処理後 $\left(\mathrm{Ni}_{0} \cdot{ }_{6} \mathrm{Zn}_{0 \cdot 4}\right)_{1-x} \mathrm{Co}_{x} \mathrm{Fe}_{2} \mathrm{O}_{4}$ および $\left(\mathrm{Ni}_{0} \cdot \mathrm{Zn}_{0} \mathrm{Zn}_{0 \cdot 3}\right)_{1-x} \mathrm{Co}_{x} \mathrm{Fe}_{2}$ $\mathrm{O}_{4}$ の組成になるように Ni および $\mathrm{Zn}$ を Co で置換し た。

Fig. 7 は $\left(\mathrm{Ni}_{0} \cdot 6 \mathrm{Zn}_{0} \cdot{ }_{4}\right)_{1-x} \mathrm{Co}_{x} \mathrm{Fe}_{2} \mathrm{O}_{4}$ の配合組成のも のを仮焼条件 $\left(950^{\circ} \mathrm{C}, 1\right.$ 時間), 本焼成条件 $1200^{\circ} \mathrm{C}$, 2 時間) で熱処理後, 炬内放冷によって室温まで冷却 した試料の $\mu_{0}-T$ 曲線を示し, Table 2 は Fig. 7 の 曲線から得られる $\mu_{0}$ の極大の温度, $\mu_{0}$ の温度变化の 少ない温度域および室温での温度係数の符号を示した ものである. Table 2 からわかるようにかかる材料を アンテナとして使用し, しかもラジオ使用温度範囲内

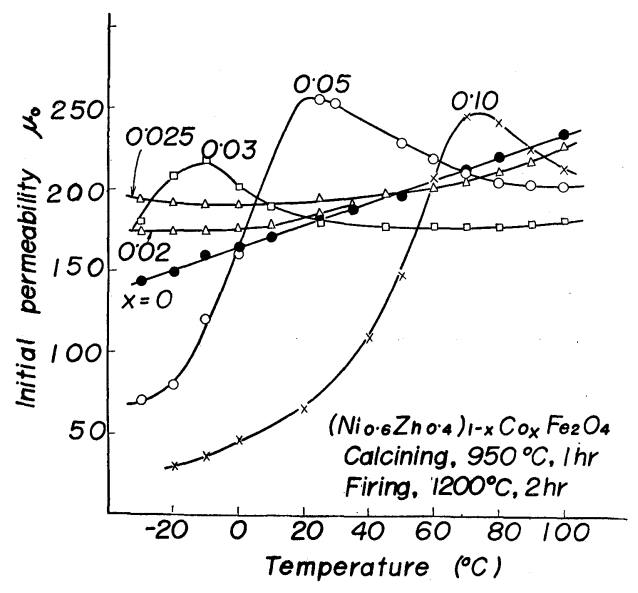

Fig. 7 Temperature dependency of initial permeability for cobalt-substituted ferrites, $\left(\mathrm{Ni}_{0.6} \mathrm{Zn}_{0 \cdot 4}\right)_{1-x} \mathrm{Co}_{x} \mathrm{Fe}_{2} \mathrm{O}_{4}$

Table 2 Characteristics for temperature dependency of initial permeability in. $\left(\mathrm{Ni}_{0 \cdot 6} \mathrm{Zn}_{0 \cdot 4}\right)_{1-x} \mathrm{Co}_{x} \mathrm{Fe}_{2} \mathrm{O}_{4}$

\begin{tabular}{c|c|c|c}
\hline $\begin{array}{c}\text { Co-ferrite } \\
\text { contents } \\
(x)\end{array}$ & $\begin{array}{c}\text { Temp. of } \\
\mu_{0} \text { max } \\
\left({ }^{\circ} \mathrm{C}\right)\end{array}$ & $\begin{array}{c}\text { Temp. range } \\
\text { of temp. } \\
\text { indept. } \mu_{0} \\
\left({ }^{\circ} \mathrm{C}\right)\end{array}$ & $\begin{array}{c}\text { Temp. } \\
\text { gradient of } \\
\mu_{0} \text { at room } \\
\text { temp. }\end{array}$ \\
\hline 0 & - & - & + \\
0.02 & Below-30 & Below 10 & + \\
0.025 & Below-30 & $-20 \sim 40$ & \pm \\
0.03 & -10 & $40 \sim 100$ & - \\
0.05 & 20 & $80 \sim$ & - \\
0.10 & 80 & $?$ & + \\
\hline
\end{tabular}

で $\mu_{0}$ の温度変化の小さいものを望むならば，

$\left(\mathrm{Ni}_{0} \cdot{ }_{6} \mathrm{Zn}_{0 \cdot 4}\right)_{1-x} \mathrm{Co}_{x} \mathrm{Fe}_{2} \mathrm{O}_{4}$ においてェが0・02〜0・025 の 籁囲のものが望ましいと考えられる。 また必要な場合 には，使用温度範囲内で $\mu_{0}$ の温度係数の小さいもの， あるいは必要とする温度係数をもった材料を単にコバ ルト含有量を变えることによって造ることができるわ けである。

さて, Co-フェライトを $\mathrm{Ni}-\mathrm{Zn}$ フェライトに固溶さ すことによって， $\mu_{0}-T$ 曲線に一つの山ができること を示したが，次にはこの極大值の大きさに着目して考 察を進めることにする. Fig. 8 は $\left(\mathrm{Ni}_{0} \cdot 7 \mathrm{Zn}_{0 \cdot 3}\right)_{1-x} \mathrm{Co}_{x}$ $\mathrm{Fe}_{2} \mathrm{O}_{4}$ の配合組成で $x=0 \cdot 10,0 \cdot 05,0 \cdot 03,0 \cdot 025$, 0.02 の場合のものについて混合原料の仮焼を行なわ ず，リング状に成形して, $1250^{\circ} \mathrm{C} て ゙ 2$ 時間焼成して 得られたフェライトの $\mu_{0}$-温度関係を, 更に, Fig. 9 ， には同じ配合組成のものを $1270^{\circ} \mathrm{C} て ゙ 2$ 時間焼成した 場合についての $\mu_{0}-T$ 曲線を示す. Fig. 8 と Fig. 9 とからわかることは

1） $\mu_{0}$ が極大になる温度は Co-フェライトの固溶 量 $(x)$ が大きいほど高い.

2） $\mu_{0}$ の極大值付近での $\mu_{0}$ の温度変化は Co-フェ ライトの固溶量 $(x)$ の大きいものほど大きい.

ということである。この関係をもう少し明確にするた めに Fig. 10 に配合組成 $\left(\mathrm{Ni}_{0 \cdot 7} \mathrm{Zn}_{0 \cdot 3}\right)_{0 \cdot 95} \mathrm{Co}_{0 \cdot 05} \mathrm{Fe}_{2} \mathrm{O}_{4}$ のものについて，仮焼を行なわず， $1150,1175,1200$ および $1275^{\circ} \mathrm{C}$ の温度でそれぞれ 2 時間保持してのち 得られたフェライトの $\mu_{0}$-温度曲線を示す。焼成温度

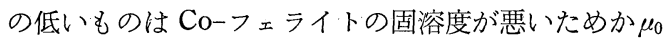
の極大は出ないが, 燒成温度が高くなるにつれて $\mu_{0}$ の 極大の生じ方が大きくなっていく，そうして燒成温度 が更に高くなれば， 単に $\mu_{0}$ の極大值と極小值が生ず

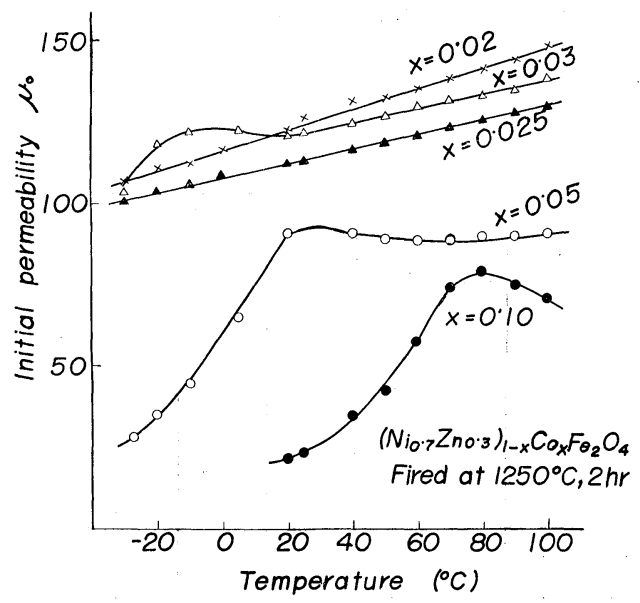

Fig. 8 Temperature dependency of initial permeability for cobalt-substituted ferrites $\left(\mathrm{Ni}_{0 \cdot 7} \mathrm{Zn}_{0 \cdot 3}\right)_{1-x} \mathrm{Co}_{x} \mathrm{Fe}_{2} \mathrm{O}_{4}$ 
るだけであって， $\mu_{0}$-温度曲線の平坦な部分すなわち $\mu_{0}$ の温度変化の小さい温度域は生じない。 また $\mu_{0}$ が 極大になる温度は烧成温度にかかわりなく一定である.

ここで報告者らが目的としている $\mu_{0}$ の温度変化の 小さいフェライト磁心について考える場合，まず $\mu_{0}$ の温度变化の小さいことが要求される温度範囲は

$-20^{\circ} \mathrm{C} \sim+50^{\circ} \mathrm{C}$ と考えなければならないが，このよ うな観点に立って，Fig. 8，9，10 から得られる結諭 を考え合せると，前述のようにCoーフェライトの固溶 量の多いものほど, $\mu_{0}$ が極大になる温度は高温側に移 動し， $\mu_{0}$ の極大值の付近での $\mu_{0}$ の変化が激しく, ま た Fig. 9 で見られるように，たとえ低温側で $\mu_{0}$ の変 化が激しくとも室温以上で温度变化の小さい材料も存 在する。しかも目的とする温度範围を $-20^{\circ} \mathrm{C} \sim+50^{\circ}$ C とするかぎり Co 含有量が $x=0.05$ のフェライトで は不充分であって， $x=0.03$ より更に少ない材料，す

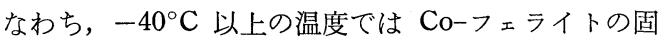
溶による $\mu_{0}$ の極大が出ないような非常に少ない量の Co-フェライトを含有する材料について考えを進めな ケればならないことになる。

Fig. 10 において，一定の Co-フェライト含有量の ものでも，熱処理の条件いかんによっては $\mu_{0}$ の極大 の生じ方が異なることを示したが，このことを考虑す ると Fig. 8 で $\mu_{0}$ の極大の生じていない，すなわち ずっと低温側で $\mu_{0}$ の極大が生じてそのために測定温 度範囲で $\mu_{0}-T$ 曲線のこう配が変化をしたというょう な状態を示していない $x=0.02, x=0.025$ のフェラ イトの場合でも，高温で焼成を行なえば， $\mu_{0}-T$ 曲線 にこう配の変化を起こしうるものと考えられる。この ことは Fig. 8 と Fig. 9 の $x=0.025$ の場合を比較す

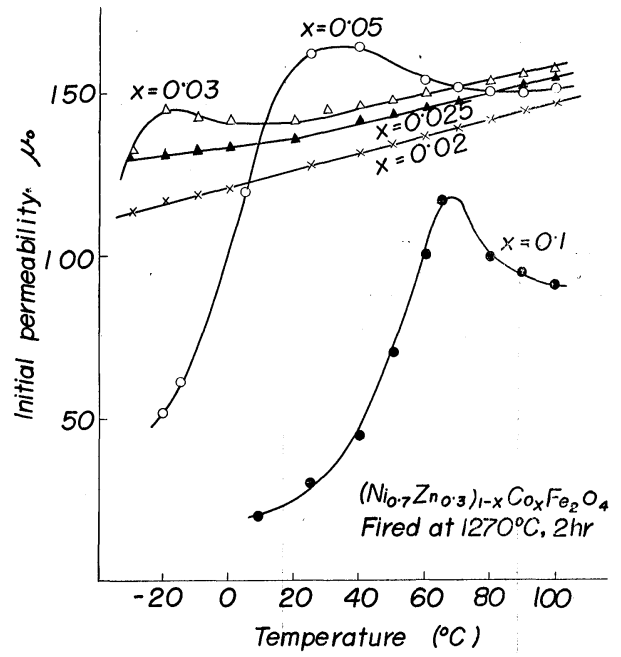

Fig. 9 Temperature dependency of initial permeability for cobalt-substituted ferrites $\left(\mathrm{Ni}_{0 \cdot 7} \mathrm{Zn}_{0 \cdot 3}\right)_{1-x} \mathrm{Co}_{x} \mathrm{Fe}_{2} \mathrm{O}_{4}$
ると, Fig. 9 の焼成温度の高いフェライトは低温側で $\mu_{0}$ の温度変化が小さくなり始めていることからもう なずける。

それゆえ, Fig. 8, 9, 10 から $-20^{\circ} \mathrm{C} \sim+50^{\circ} \mathrm{C}$ の 温度範团で $\mu_{0}$ の温度変化の小さい材料を得るために は,

1）Coーフェライトの量が $x=0.03$ より少ないこと.

2）1)の材料について熱処理を充分に行なうこと.

という結論が得られる。

ところがよく知られているように，熱処理を充分行 なうために，焼成温度を上げたり最高温度に長時間保

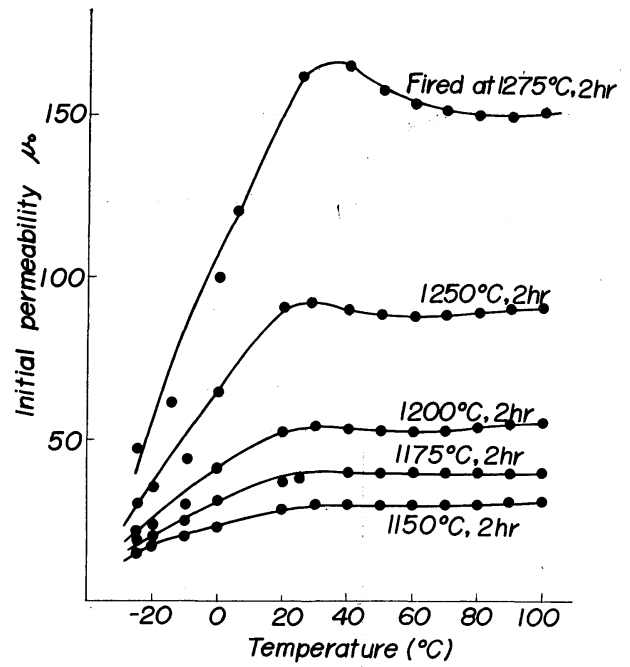

Fig. 10 Temperature dependency of initial permeability for $\left(\mathrm{Ni}_{0.7} \mathrm{Zn}_{0 \cdot 3}\right)_{0 \cdot 95} \mathrm{Co}_{0 \cdot 05} \mathrm{Fe}_{2} \mathrm{O}_{4}$ fired at various temperatures

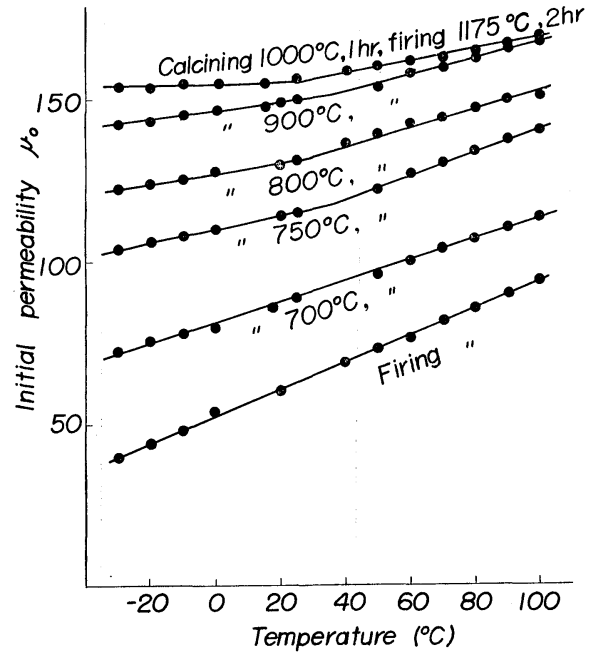

Fig. 11 Temperature dependency of initial permeability for $\left(\mathrm{Ni}_{0 \cdot 6} \mathrm{Zn}_{0 \cdot 4}\right)_{0 \cdot 98} \mathrm{Co}_{0 \cdot 02} \mathrm{Fe}_{2} \mathrm{O}_{4}$ obtained by different heat-treatment 
持するようなことをすれば， $\mu_{0}$ 以外のフェライトの特 性，主として損失が悪くなり実用上よくないので，本 焼成に先立って焼成温度よりずっと低い温度で仮焼を 行なうことによって総合特性をよくすることを考える ベきである。

Fig. 11 は配合組成 $\left(\mathrm{Ni}_{0} \cdot{ }_{6} \mathrm{Zn}_{0} \cdot{ }_{4}\right)_{0} \cdot{ }_{93} \mathrm{Co}_{0} \cdot{ }_{02} \mathrm{Fe}_{2} \mathrm{O}_{4}$ のも

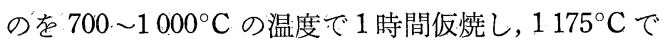
2 時間本焼成したものの $\mu_{0}$-温度関係を表わす図であ る、仮燒を行なわない場合には， $\mu_{0}$ の温度こう配は (われわれが行なった測定温度範用では)どの温度でも 一定であるが，仮焼を行なうと，測定温度よりずっと 低温側で $\mu_{0}$ の極大が生じているためか, 仮焼温度が 高くなるにつれて, 室温以下での $\mu_{0}$ の温度变化は小 さくなっていき, 仮焼温度 $1000^{\circ} \mathrm{C} て ゙ \mu_{0}$ の温度変化 がほとんどなくなることがわがる。

Fig. 12 は配合組成 $\left(\mathrm{Ni}_{0 \cdot 6} \mathrm{Z}_{0^{\cdot} 4}\right)_{0} \cdot{ }_{975} \mathrm{Co}_{0} \cdot{ }_{025} \mathrm{Fe}_{2} \mathrm{O}_{4}$ につ いて Fig. 11 と同じ関係を示すものである。この場合

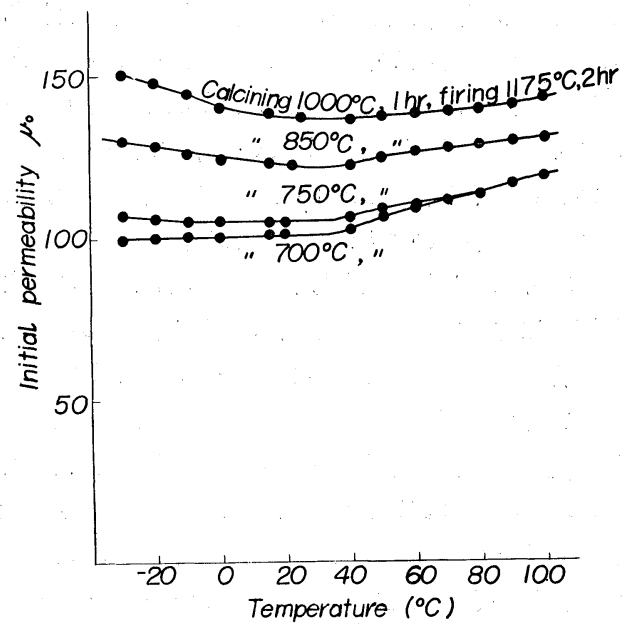

Fig. 12 Temperature dependency of initial permeability for $\left(\mathrm{Ni}_{0.6} \mathrm{Zn}_{0 \cdot 4}\right)_{0 \cdot 975} \mathrm{Co}_{0 \cdot 025} \mathrm{Fe}_{2} \mathrm{O}_{4}$ obtained by different heat-treatment

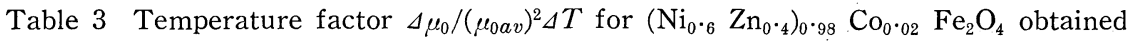
by different heat-treatment and $\mu_{0}, Q$ at 1 M.C. for these materials

\begin{tabular}{|c|c|c|c|c|c|c|c|}
\hline \multicolumn{2}{|c|}{$\begin{array}{c}\text { Calcining } \\
\text { temp., keep time } \\
\left({ }^{\circ} \mathrm{C}\right) \\
(\mathrm{hr})\end{array}$} & \multicolumn{2}{|c|}{$\begin{array}{c}\text { Firing } \\
\text { temp., keep. time } \\
\left({ }^{\circ} \mathrm{C}\right) \\
\text { (hr) }\end{array}$} & $\begin{array}{l}\text { Temperatur } \\
\text { Temp. range } \\
\left({ }^{\circ} \mathrm{C}\right)\end{array}$ & $\begin{array}{l}\text { e factor } \\
\Delta \mu_{0} /\left(\mu_{0 \alpha v)^{2}}\right. \\
\qquad \Delta T \times 10^{6}\end{array}$ & $\begin{array}{l}\text { at } 1 \text { M.C., room } \\
\text { temp. }\end{array}$ & $\begin{array}{c}\text { at } 1 \text { M.C., room } \\
\text { temp. }\end{array}$ \\
\hline 700 & 1 & 1175, & 2 & $-30 \sim 100$ & $34 \cdot 3$ & $88 \cdot 6$ & 252 \\
\hline 750 & 1 & " & " & $\begin{array}{l}-27 \sim 26, \\
26 \sim 100,\end{array}$ & $\begin{array}{l}18 \cdot 3 \\
20 \cdot 15\end{array}$ & 119 & 225 \\
\hline 800 , & 1 & $"$ & ' & $\begin{array}{l}-27 \sim 26, \\
26 \sim 100\end{array}$ & $\stackrel{8}{12 \cdot 23}$ & 135 & 148 \\
\hline 850 , & 1 & $" \prime$ & " & $\begin{array}{r}-25 \sim 26, \\
26 \sim 100\end{array}$ & $\begin{array}{r}5 \cdot 4 \\
11 \cdot 4\end{array}$ & 140 & 142 \\
\hline 900 & 1 & $"$ & " & $\begin{array}{r}-25 \sim 26 \\
26 \sim 100\end{array}$ & $\begin{array}{c}4 \cdot 96 \\
10 \cdot 9\end{array}$ & 149 & 131 \\
\hline 950 , & 1 & $"$ & " & $\begin{array}{r}-30 \sim 30 \\
30 \sim 100\end{array}$ & $\begin{array}{l}2 \cdot 2 \\
7 \cdot 3\end{array}$ & $152 \cdot 1$ & 124 \\
\hline 1000 & 1 & $" \prime$ & " & $\begin{array}{r}-30 \sim 32, \\
32 \sim 100\end{array}$ & $\begin{array}{l}1 \cdot 81 \\
7 \cdot 41\end{array}$ & 157 & 103 \\
\hline 1050 & 1 & $" \prime$ & " & $\begin{array}{r}-30 \sim 40 \\
\quad 40 \sim 100\end{array}$ & $\begin{array}{l}2 \cdot 28 \\
7 \cdot 26\end{array}$ & 164 & $92 \cdot 5$ \\
\hline
\end{tabular}

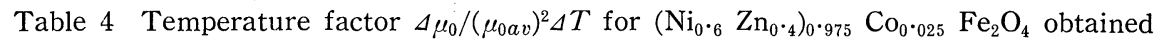
by different heat-treatment and $\mu_{0}, Q$ at 1 M.C. for these materials

\begin{tabular}{|c|c|c|c|c|c|c|c|}
\hline \multicolumn{2}{|c|}{$\begin{array}{l}\text { Calcining } \\
\text { temp., keep time } \\
\left({ }^{\circ} \mathrm{C}\right) \\
\text { (hr })\end{array}$} & \multicolumn{2}{|c|}{$\begin{array}{c}\text { Firing } \\
\text { temp., keep. time } \\
\left({ }^{\circ} \mathrm{C}\right) \\
(\mathrm{hr})\end{array}$} & \multicolumn{2}{|c|}{$\begin{array}{cc}\text { Temperature factor } \\
\text { Temp., range } & \Delta \mu_{0} /\left(\mu_{0 \alpha \gamma}\right)^{2} \\
\left({ }^{\circ} \mathrm{C}\right) & \Delta T \times 10^{6}\end{array}$} & \multirow{2}{*}{$\begin{array}{c}\text { at } 1 \text { M.C., room } \\
\text { temp. } \\
102\end{array}$} & \multirow{2}{*}{$\begin{array}{c}\begin{array}{c}Q \\
\text { at } 1 \mathrm{M.C.,} \text { room } \\
\text { temp. }\end{array} \\
240\end{array}$} \\
\hline 700 , & 1 & 1175 , & 2 & $\begin{array}{r}-40 \sim 40 \\
40 \sim 100\end{array}$ & $\begin{array}{c}9 \cdot 51 \\
19 \cdot 4\end{array}$ & & \\
\hline 750 & 1 & " & " & $\begin{array}{c}-30 \sim 40, \\
\quad 40 \sim 100,\end{array}$ & $\begin{array}{l}-1 \cdot 23 \\
14 \cdot 5\end{array}$ & 106 & 217 \\
\hline 800 , & 1 & " & " & $\begin{array}{r}-30 \sim 40, \\
40 \sim 100\end{array}$ & $\begin{array}{l}-6 \cdot 07 \\
10 \cdot 5\end{array}$ & 115 & 215 \\
\hline 850 , & 1 & " & " & $\begin{array}{l}-30 \sim 34, \\
34 \sim 100\end{array}$ & $\begin{array}{r}-8 \cdot 97 \\
8 \cdot 51\end{array}$ & 122 & 191 \\
\hline 900 , & 1 & " & " & $\begin{array}{r}-30 \sim 22 \\
22 \sim 100\end{array}$ & $\begin{array}{r}-11 \cdot 5 \\
2 \cdot 41\end{array}$ & 160 & 80 \\
\hline 1000 , & 1 & "I & " & $\begin{array}{r}-30 \sim 30 \\
30 \sim 100\end{array}$ & $\begin{array}{r}-12 \cdot 86 \\
5 \cdot 14\end{array}$ & 138 & 125 \\
\hline 1050 , & 1 & "I & " & $\begin{array}{r}-30 \sim 30, \\
30 \sim 80\end{array}$ & $\begin{array}{r}-18 \cdot 2 \\
1 \cdot 55\end{array}$ & $119 \cdot 8$ & 131 \\
\hline
\end{tabular}


にも, 仮焼温度が高くなるにつれて, ずっと低温側で $\mu_{0}$ の極大が生じるために起こると思われる $\mu_{0}$-温度曲 線の変化が見られる。

ただ Fig. 11 と Fig. 12 の異なるところは， $\mu_{0}-T$ の関係が平坦になる仮焼温度は, 前者の場合には 1000 ${ }^{\circ} \mathrm{C}, 1$ 時間であるにたいし, 後者の場合には $700^{\circ} \mathrm{C}$, 1 時間ということである.このことは Fig. 8,9 を比 較検討すればわかるように, 同じ熱処理条件では, Co-フェライトをより多く固溶するもののほうが， $\mu_{0}$ の極大の近傍で $\mu_{0}-T$ 曲線の立ち上がり方が大きいと いうことから， $\mu_{0}-T$ 曲線を同じ程度に引き上げる(こ の場合には $\mu_{0}-T$ 曲線を平担にする)には, Co-フェラ イトの固溶量が少ないもののほうがより多くの熱処理 を必要とすることになるためであると考えられる.

Table 3, 4 には, Fig. 11, 12 から得られる $\mu_{0}-T$ の変化を $\Delta \mu_{0} /\left(\mu_{0 a v .}\right)^{2} \Delta T$ の值として表わした．また これらの熱処理条件での $\mu_{0}, Q$ (1 Mc 室温)の值をも 併記した。

Table 3, 4 から， $\mu_{0}$ の温度係数は仮焼温度によっ て系統的に変化していくことを理解することができる。

\section{5. 結 論}

初透磁率 $\mu_{0}$ の温度変化の小さい $\mathrm{Ni}-\mathrm{Zn}$ 系フェライ 卜を造る目的で, 種々の作成条件を検討した結果, 次 の結論が得られた。

（1） $\mathrm{Ni}-\mathrm{Zn}$ 系フェライトの $\mu_{0}$ の温度変化を小さ くするためには，単に作成時の熱処理の条件を变える だけでは飛躍的な向上は得られない。

（2） Ni-Zn フェライトに適当量のCo-フェライト を固溶することによって， $\mu_{0}$ の温度変化の模様を任意 に変えることができるが, 通常フェライト磁心が使用 される温度範囲 $-40^{\circ} \mathrm{C} \sim+50^{\circ} \mathrm{C}$ で $\mu_{0}$ の温度変化を
小さくするには $\left(\mathrm{Ni}_{0} \cdot 7 \mathrm{Zn}_{0 \cdot 3}\right)_{1-x} \mathrm{Co}_{x} \mathrm{Fe}_{2} \mathrm{O}_{4}$ および

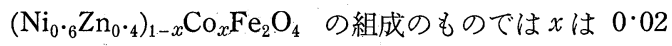
から 0.025 の範囲のものがよい.

(3) Coーフェライトの固溶量によって $\mu_{0}$ が極大に なる温度は異なるが，Co-フェライトの固溶量の多い ものほどこの温度は高温側に移る。

（4）同じ熱処理条件では $\mu_{0}$ の極大の示し方は Co ーフェライトの固溶量の多いものほど大きい.

（5）同じ固溶量の Co-フェライトを含む場合には， 焼成温度の高いもののほうが $\mu_{0}$ の極大の示し方が大 きい.

(6) $\left(\mathrm{Ni}_{0 \cdot 6} \mathrm{Zn}_{\left.0^{\cdot} \cdot\right)_{1-x}} \mathrm{Co}_{x} \mathrm{Fe}_{2} \mathrm{O}_{4}\right.$ および $\left(\mathrm{Ni}_{0} \cdot 7 \mathrm{Zn}_{0 \cdot 3}\right)_{1-x}$ $\mathrm{Co}_{x} \mathrm{Fe}_{2} \mathrm{O}_{4}$ のいずれの場合でも， $x=0.025$ 以下のも のでは, 仮䍃を行なわなければ, $1270^{\circ} \mathrm{C}$ 以下の熱処 理では $-30^{\circ} \mathrm{C} \sim+50^{\circ} \mathrm{C}$ の温度範囲で Co-フェライト の固溶による影響は見られない。

( 7 ） $x=0.025$ 以下のものについて, $\mu_{0}$ の温度変 化を $-30^{\circ} \mathrm{C} \sim+50^{\circ} \mathrm{C}$ の温度範囲でなくするために は， $\mu_{0}, Q$ 特性との関係上仮焼を行なわなりればなら ないが, 結論. (4) からわかるように, 同じ程度に $\mu_{0}$ の温度変化をなくするためにはCoーフェライトの固溶 量の少ないものは燒仮温度を高くしなければならない。

\section{参考 文 献}

1) J. Smit and H.P.J. Wijn, Ferrites, p. 252 (1959)

2) 武井, 和田, 二条, 電学誌, 76,1449 , (Dec. 1956)

3) 城阪, 杉原, 電子機器部品, p. 270, (1960)

4) J.K. Galt et al., Phys. Rev. 79, 391 (1950)

D.W. Healy, Jr., Phys. Rev. 86, 1009 (1952)

5) C.M. van der Burgt et al., Philips Res. Rep., 12, 97 (1957)

6) R.M. Bozorth et al., Phys. Rev., 991788 (1955) D.E. Tannenwald, Phys. Rev., 99, 463 (1955) 